\title{
Exploration of Novel Plant Growth Promoting Bacteria Stenotrophomonas maltophilia MTP42 Isolated from the Rhizospheric Soil of Coleus forskohlii
}

\author{
Tisha Patel and Meenu Saraf
}

Department of Microbiology and Biotechnology, School of sciences, Gujarat University, Ahmedabad-380009, Gujarat, India

*Corresponding author

\section{A B S T R A C T}

The current exploration is anticipated for isolation and characterization of diversified plant growth promoting activities of coleus rhizobacteria and augmentation of coleus plant growth. Anincongruous group of bacteria known as the plant growth promoting bacteria are found in the rhizosphere, they are seen at the root surfaces and in union with roots.

\begin{tabular}{|l|}
\hline Ke y w or d s \\
Coleus, \\
Stenotrophomonas \\
maltophilia, Plant \\
growth promoting \\
rhizobacteria, MTP42, \\
Rhizosphere.
\end{tabular}
Thereafter, they directly or indirectly improve the scope and quality in the growth of the plant. Though the mechanism of them whether directly or indirectly is not well understood, but its production of plant growth regulators viz., indole 3-acetic acid, gibberellic acid, indole butyric acid and their enmity against plant pathogenic microorganisms by bearing siderophores, antibiotics, phosphates and other nutrients. In this paper we reported the isolation of Stenotrophomonas maltophilia from rhizosphere of coleus forskohlii Briq. Procured from the district of Anand, Gujarat. The isolate was characterized for morphological and biochemical attributes and was identified as Stenotrophomonas maltophilia MTP42 on the basis of 16S-rRNA partial sequence analysis. The bacterial isolate MTP42 (KT428130) showed of inorganic phosphate solubilization (818ppm), Acid phosphatase activity $(1.62 \mathrm{IU} / \mathrm{ml})$, IAA production $(93 \mu \mathrm{g} / \mathrm{ml})$, Ammonia production $(80$ $\mu \mathrm{g} / \mathrm{ml}$ ) and able to produce siderophore and $\mathrm{HCN}$ under optimized growth conditions and Trehalose, as carbon source. The following research revealed that Stenotrophomonas maltophiliaMTP42 is a propitious plant growth promoting rhizobacteria with wide array of components. Leading report of using Stenotrophomonas maltophilia MTP42 as plant growth promoting rhizobacteria from Coleus rhizosphere and use of this isolate MTP42 as Plant growth promoting rhizobacteria attempts attractive way to replace chemical fertilizers and pesticides.

\section{Introduction}

The appellation Rhizobacteria represents a batch of rhizosphere bacteria capable of colonizing the root environment. The beneficial and plant growth promoting and root colonizing rhizobacteria are exemplified by diacritic traits: (1) root can be inhabited (2) they can grow in the habitats associated with the surface of the root and they can live in competition with other microbes, and (3) plant development must be supported (Adesemoye, 2013). The soil or seeds when coated with PGPR invigorate the growth of the plant directly/indirectly by supplying nutrients or by decreasing the destruction caused by soil-borne plant pathogens (Ramadan, 2016). The foreboding of 
rhizosphere was an perilous zone of soil surrounding the roots where microbe populations are fervent by root activities has been extended to include the soil surrounding a root in which physical, chemical and biological properties have been changed by root growth and activity (Haldar and Sengupta, 2015). The bacteria are found to affect the plant physiology to a great extent, as they are the most abundant microbes in the rhizosphere and majorly causing changes in the root colonizing characteristics (Krogan, 2006). Those microbes are selected by the plant whose contribution is found most in releasing the organic compounds by creating a selective environment (Davey and O'toole, 2000). They are found to implant a positive impact on the plants by inhabiting the plant roots from unambiguous control mechanisms to an indirect effect (Ptak, 2015). Thus, plant growth promoting bacteria can be epitomized as the ones which are beneficial to the plants and the ones who inhabit the rhizosphere (Pielach, 2008). In recent times, plant growth promoting rhizobacteria have gained great importance as they are a bionetwork of bacteria serving as a crucifier in the biosphere (Kumar, 2007).

A diversity of bacteria like Pseudomonas, Azospirillum, Azotobacter, Klebsiella, Enterobacter, Alcaligenes, Arthrobacter, Burkholderia, Bacillus and Serratia have been reported to increase the plant growth (Tilak, 2005). The important traits of plant promoting bacteria are; Biocontrol (control of plant diseases), Biofertilizer (enhanced nutrient uptake), Bio stimulants (production of phytohormone), systemic resistance enhancement and production of antibiotics or siderophore (Saharan and Nehra, 2011). PGPB serves as a defence role by releasing heavy metal in the rhizosphere which suppresses the growth of pathogens as they lack nutrition (Siderophore), solubilise phosphate to increase the intake of phosphorus, nitrogen fixation and antibiotic released by them reduces the growth of pathogens (Ramakrishna, 2014). Certain hormones like Auxin (IAA), gibberellins, cytokinins and ethylene are released by plant growth promoting bacteria which helps in promoting their growth. Indole acetic acid (IAA) microbialy is enhanced by tryptophan which are released from the roots (Glick, 2012). Stenotrophomonas maltophilia is a known bacteria in the rhizosphere of corn, beets, cereal crops, cruciferous plants and are also found in the internal tissue of potato plants (Rania, 2016). S. maltophilia though does not control potato brown rot but it has been proven as an important biocontrol against fungal and oomycetous pathogens (Kumar and Audipudi, 2015). Stenotrophomonas maltophilia constrains the growth of Rhizoctonia solani and Verticillium dahliae in vitro, apparently because of antibiosis and provision of lytic enzymes (Narayanasamy, 2013). In the present research heterogeneous bacteria Stenotrophomonas maltophilia screened from the $C$. forskohlii rhizosphere has been characterized in terms of its plant growth promoting traits and Indole acetic acid production (Berg, 1999). The aim of this study was to assess the auxin production through chromatography and to investigate its plant growth promoting traits.

\section{Materials and Methods}

\section{Site description of soil sampling and collection}

Soil samples were taken in April 2014 from the rhizosphere of Coleus forskohlii which was procured from the irrigated fields of Anand district of Gujarat at latitude of $22.5645^{\circ} \mathrm{N}, 72.9289^{\circ} \mathrm{E}$. The samples were taken in polythene bags and preserved at $4^{0} \mathrm{C}$ and it was processed within 48 hours. 
Enrichment and isolation of Stenotrophomonas maltophilia

A bacterium (MTP 42) was isolated from the rhizosphere of a medicinal plant Coleus forskohlii, on normal nutrient agar medium with glucose at $\mathrm{pH} 7$, temperature $37^{\circ} \mathrm{C}$ and with incubation period $48 \mathrm{hrs}$. The bacterial isolate was further characterized by its cultural conditions, morphological (Gram's staining) and biochemical characteristics (Bergey's Manual of Systematic Bacteriology).

\section{Growth profile study}

To examine growth profile of the isolate under liquid culture conditions, $100 \mathrm{ml}$ broth in tryptic soybean broth (TSB), Hi media laboratories, Mumbai, India was used to inoculate the organism at $1 \%$ inoculum level. Viable cell count method was used to study the growth curve of the organism. $50 \mathrm{ml}$ of Tryptic soybean broth was inoculated by early exponential phase culture to study the growth profile. The Mean growth rate constant (K) was calculated by withdrawing the isolate every 2 hrs:

$\mathrm{K}=3.322(\log \mathrm{Zt}-\log \mathrm{Z} 0) / \mathrm{Dt}$

Where $\mathrm{Z0}$ and $\mathrm{Zt}$ are the initial and final cell populations

While, Dt is the difference in culture time. (Pandey and Maheshwari 2007)

\section{Plant growth promoting attributes}

\section{Phosphate solubilization activity}

$\mathrm{P}$ solubilisation was checked using tricalcium phosphate as insoluble phosphate. Spot inoculation of the isolate was done in the centre of the Pikovyskyaya's medium amended with bromophenyl blue. The plates were then incubated at $37^{\circ} \mathrm{C}$ for 48 to $72 \mathrm{hrs}$. Phosphate solubilisation was checked in the form of a clear halo formed around the colony representing the production of organic acids as a possible mechanism of the phosphate solubilisation.

Quantitative P solubilisation was carried out in liquid Pikovskyaya's medium in $250 \mathrm{ml}$ flasks for $14 \mathrm{~d}$. The concentration of the soluble phosphate in the supernatant was estimated every $7 \mathrm{~d}$ by stannous chloride $\left(\mathrm{SnCl}_{2}, 2 \mathrm{H}_{2} \mathrm{O}\right)$ method (Gaur, 1990).

A simultaneous change in the $\mathrm{pH}$ was recorded. Phosphate solubilization activities were screened by measuring the clearing zone surrounding the developed bacterial colony via calculation of phosphate solubilization index:

Phosphate Solubilization Index $=\mathrm{A} / \mathrm{B} \times 100$

$\mathrm{A}=$ total diameter (colony + halo zone)

$\mathrm{B}=$ diameter of colony

\section{Assay for siderophore production}

According to the methodology described by Gopalakrishnan, S., (2012), bacteria were streaked on the centre of Chrome Azurol S (CAS) agar media and incubated at $30^{\circ} \mathrm{C}$ for $48 \mathrm{~h}$. When the bacteria consume iron, present in the blue-colored CAS media, yelloworange halos around the colonies indicate the incidence of siderophores. Percent decolorization (Siderophore Units) was calculated by using following formula

$\%$ decolorization $=\mathrm{Ar}-\mathrm{As} \times 100$

Where,

$\mathrm{Ar}=$ Absorbance of reference at $630 \mathrm{~nm}$ and As $=$ Absorbance of sample at $630 \mathrm{~nm}$. 


\section{Quantitative estimation}

One $\mathrm{ml}$ actively growing isolates with 0.5 O.D. at $600 \mathrm{~nm}$ inoculated in $50 \mathrm{ml}$ of MM9 medium in $250 \mathrm{ml}$ EM flasks. All flasks were incubated at $30^{\circ} \mathrm{C}$ for $30 \mathrm{~h}$ on orbital shaker. After $30 \mathrm{~h}$, all cultures were centrifuged at $5,000 \mathrm{rpm}$ for 20min. Supernatant was collected and tested for $\mathrm{pH}$, fluorescence and siderophore production.

A simultaneous change in growth pattern of the isolate was also carried out. Catecholate types of siderophores were checked by Arnow's method (Arnows 1937) and for hydroxymate type of siderophores Csaky's method (Csakya, 1948) was used.

\section{Hydrogen cyanide production}

The production of Hydrocyanic acid $(\mathrm{HCN})$ was detected by spreading $1 \mathrm{ml}$ of $24 \mathrm{~h}$ old broth culture on nutrient agar slants and incubation of the slants with the Whatman filter paper flooded with the solution containing $0.5 \%$ picric acid in $2 \%$ sodium carbonate inserted in the tubes.

After 24-48 HCN production was checked on the basis of changes in colour from yellow to light brown, moderate brown or strong brown of the yellow filter paper strips.

\section{Ammonia production}

Ammonia production was estimated by Nessler's reagent. Freshly grown culture was inoculated into $4 \mathrm{ml}$ of peptone water and incubated for $48 \mathrm{~h}$ at $37^{\circ} \mathrm{C}$.

Broth was collected, centrifuged and $1 \mathrm{ml}$ Nessler's reagent was added to $1 \mathrm{ml}$ of supernatant and the volume of this mixture was made up to $10 \mathrm{ml}$ by addition of ammonia free distilled water. Development of brown to yellow color was a positive test for ammonia production and optical density was measured by spectrophotometer at $450 \mathrm{~nm}$. The concentration of ammonia was estimated based on a standard curve of ammonium sulfate ranging from 0.1 to $1 \mu \mathrm{mol} \mathrm{ml}$.

\section{Exopolysaccharide (EPS) production by the isolate}

EPS production was studied in medium containing 5\% sucrose as carbohydrate source (Modi et al., 1989) $10 \mathrm{ml}$ of culture suspension was collected after 5-6 days and centrifuged at 30,000 rpm for 45 mins. Add thrice the volume of chilled acetone.

EPS will be separated from the mixture in the form of a slimy precipitates. It was then collected on a predried filter paper. They were then dried overnight at $50^{\circ} \mathrm{C}$. Weigh the filter paper again after overnight drying.

The EPS produced will be shown in the increased weight of the filter paper.

\section{Molecular Identification of Bacterial Isolate}

Pure culture of MTP42 bacterial isolate was grown until log phase achieved and genomic DNA was isolated (Bazzicalupo, 1995). The amplification of 16S rRNA gene was done by using universal bacterial primer 1492R (5'TACGGYTACCTTGTTACGACTT-3') and 27F (5' - AGAGTTTGATCMTGGCTCAG3) (Pandey, et al., 2005). The PCR product was sequenced at Chromous Biotech Pvt Ltd. The sequences obtained were compared with those from the GenBank using the BLAST program and Phylogenetic trees reconstructions were obtained by the Neighbor joining method 1000 bootstrap replicates were performed to assess the statistical support for each branch in the tree (Tamura et al., 2007). 


\section{Results and Discussion}

\section{Isolation and characterization}

Out of the 72 bacteria isolated from the coleus rhizosphere, one of the colonies showed mucoid and water bubble morphology (plate 1A). On the basis of culture, morphological, biochemical and molecular characteristics, the bacterial isolate was identified as Stenotrophomonas maltophilia MTP 42 (Table 1; Fig. 1).

\section{Growth profile study}

Growth curve of isolated colony was determined by spectrophotometric method. Growth profile (Figure 2) of the isolate was determined by inoculating early exponential phase culture in $50 \mathrm{ml}$ of nutrient broth under aseptic conditions. Samples were withdrawn every 2 hours. Mean growth rate constant (K) was calculated using the formula: $\mathrm{K}=3.322(\log \mathrm{Zt}-\mathrm{Z0}) / \mathrm{Dt}$; Where $\mathrm{Z} 0$ and $\mathrm{Zt}$ are the initial and final cell populations, While Dt is the difference in culture time. It was a fast growing isolate. K value of MTP42 $0.87 \pm 0.04$ $\mathrm{h}^{-1}$. According to the result MTP42 is found to be the fastest grower and on the basis of its growth profile other PGPR parameters were designed.

\section{Phosphate solubilising activity}

Results shows that the isolate is a good Psolubilizer and it showed zone of phosphate solubilisation on solid Pikovskyaya's medium after 4 days of incubation at $30 \pm 2^{\circ} \mathrm{C}$ (Plate 1B). In liquid medium the phosphate solubilization was observed as $(40 \mu \mathrm{g} / \mathrm{ml})$. The $\mathrm{pH}$ of the medium also showed a decrease from 7.1 to a maximum of 3.4 after $21 \mathrm{~d}$ in MTP 42. However, from the observation it is clear that no correlation could be established between the degree of $\mathrm{P}$ - solubilization and the final $\mathrm{pH}$ of the medium (Tank and Saraf 2003) (Table 2; Figs. 3 and 4).

\section{Assay for siderophore production}

Siderophore production by the isolate carried out on solid CAS blue agar showed a clear zone of decolorization representing iron chelation by the isolate in the medium. The zone of dye decolorization observed was 23 $\mathrm{mm}$ after $120 \mathrm{~h}$ and the siderophore production was $28 \mu \mathrm{g} / \mathrm{ml}$ after $96 \mathrm{~h}$ respectively. Siderophore production reduced thereafter on further incubation up to $144 \mathrm{~h}$. Hydroxamate type of siderophore production was seen from qualitative and quantitative estimation (Fig. 5).

Chandra et al., (2007) reported production of $32 \mu \mathrm{g} / \mathrm{ml}$ of hydroxamate type of siderophore by M.loti after $48 \mathrm{~h}$ of incubation. Production of siderophore results in siderophore mediated competition among the bacteria which further results into exclusion of siderophore non producer pathogens from the rhizosphere due to lack of iron depletion for sclerotia germination and hyphal growth. This was supported by Singh et al., (2008) who showed that rhizosphere isolate Bacillus subtilis $\mathrm{BN} 1$ inhibited the growth of $M$. phaseolina upto $60 \%$.

\section{Hydrogen cyanide (HCN) and ammonia production by the isolate}

Ammonia production was studied from $10^{\text {th }}$ to $13^{\text {th }}$ days of incubation as per metho given by dye (1968). Maximum concentration of ammonia production was observed in the isolate MTP42 and it was $43 \mu \mathrm{g} / \mathrm{ml}\left(10^{\text {th }}\right.$ day) and $45 \mu \mathrm{g} / \mathrm{ml}\left(11^{\text {th }}\right.$ day). Consecutive reading after $11^{\text {th }}$ days of incubation showed that there was a decrease in ammonia production in all isolates. This continued till 14 days. Maximum ammonia production was seen on the $11^{\text {th }}$ day after which there is a decrease in the ammonia production. Ammonia released by diazotrophs is one of the most important traits of PGPR's which benefits the crop (Kundu, 1987). This accumulation of 
ammonia in soil may increase in $\mathrm{pH}$ creating alkaline condition of soil at $\mathrm{pH}$ 9-9.4. It suppresses the growth of certain fungi and nitrobacteria due to it potent inhibition effect. It also upsets the microbial community and inhibits germination of spores of many fungi (Martin 1982). Christiansen et al., (1991) have reported that level of oxygen limiting conditions. However, Joseph et al., (2007) reported ammonia production in $95 \%$ of isolates of bacillus followed by pseudomonas (94.2\%), Rhizobium (74.2\%) and Azotobacter $(45 \%)$.

Fig.1 The isolated and pure colonies of Stenotrophomonas maltophilia

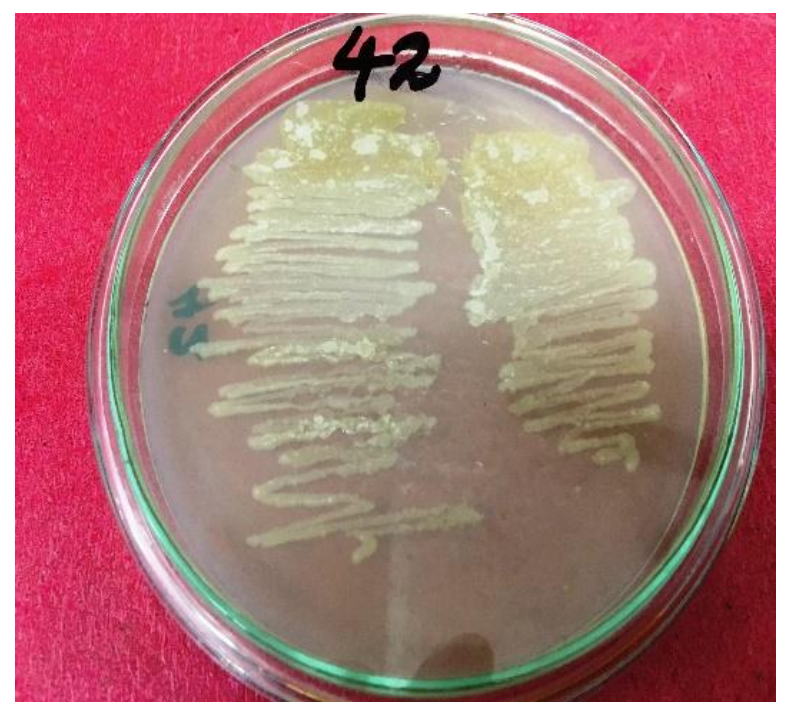

Fig.2 Logarithmic growth studies of MTP 42 isolate

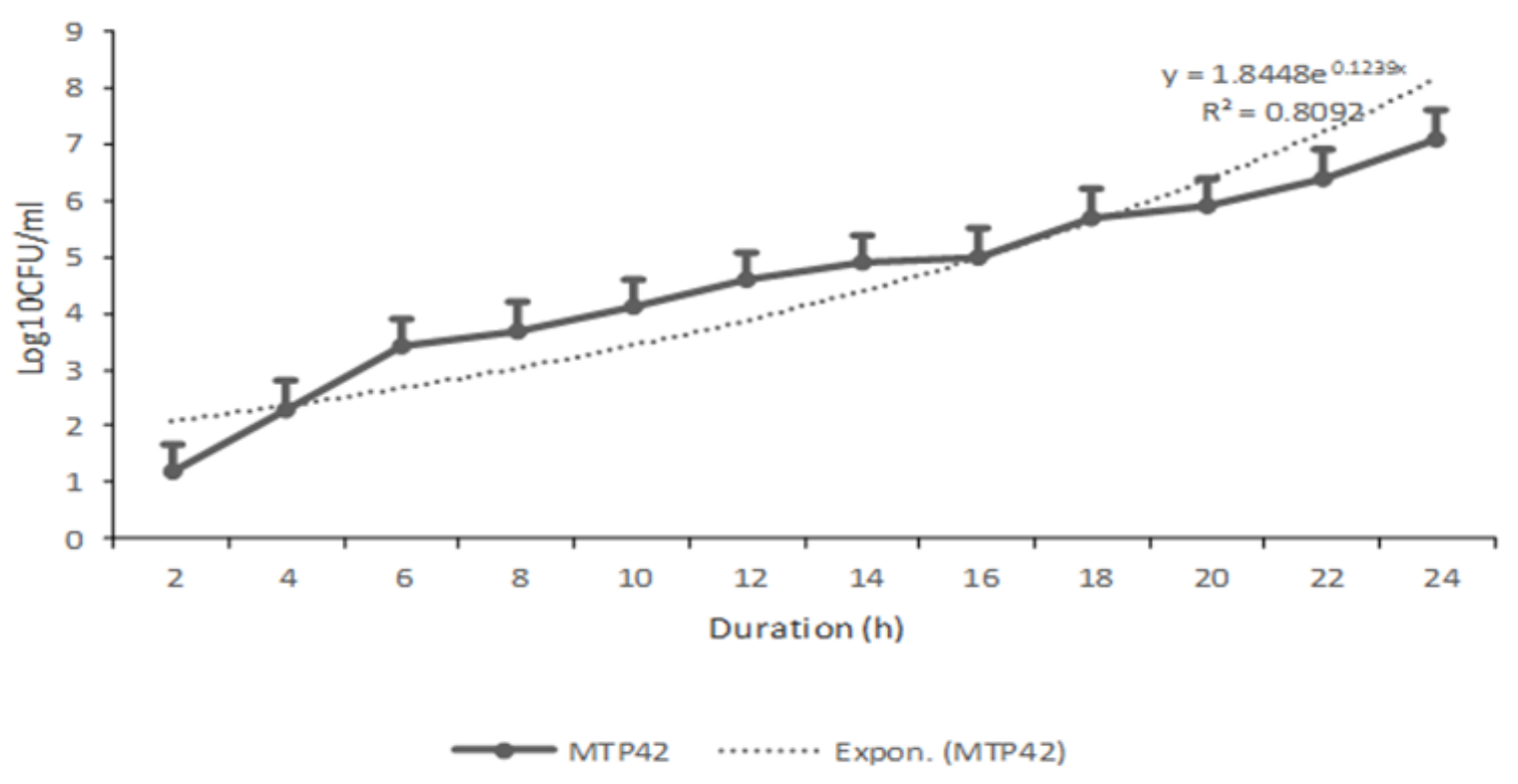


Fig.3 Phosphate solubilisation by Stenotrophomonas maltophilia MTP42

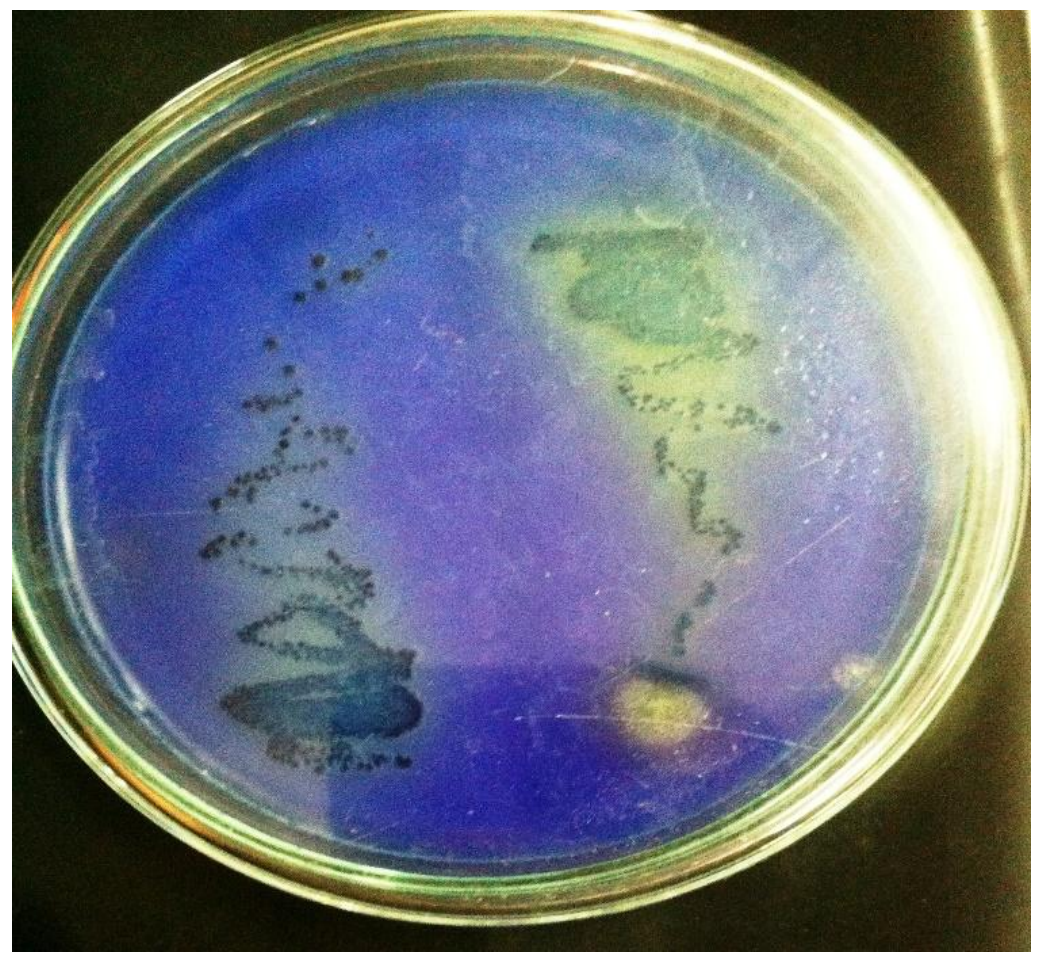

Fig.4 Phosphate solubilisation by Stenotrophomonas maltophilia MTP 42

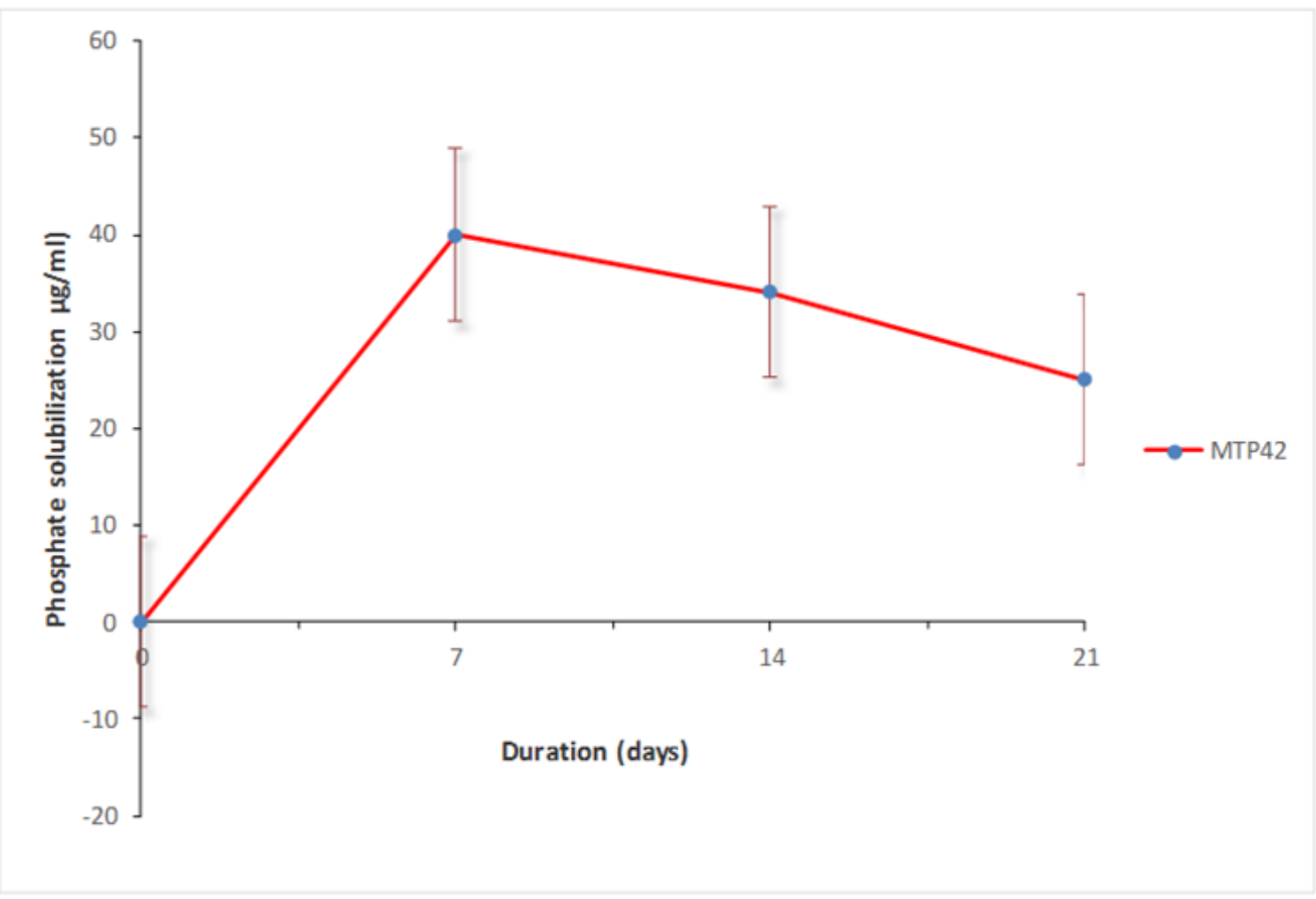


Fig.5 The siderophore production of the isolate MTP 42

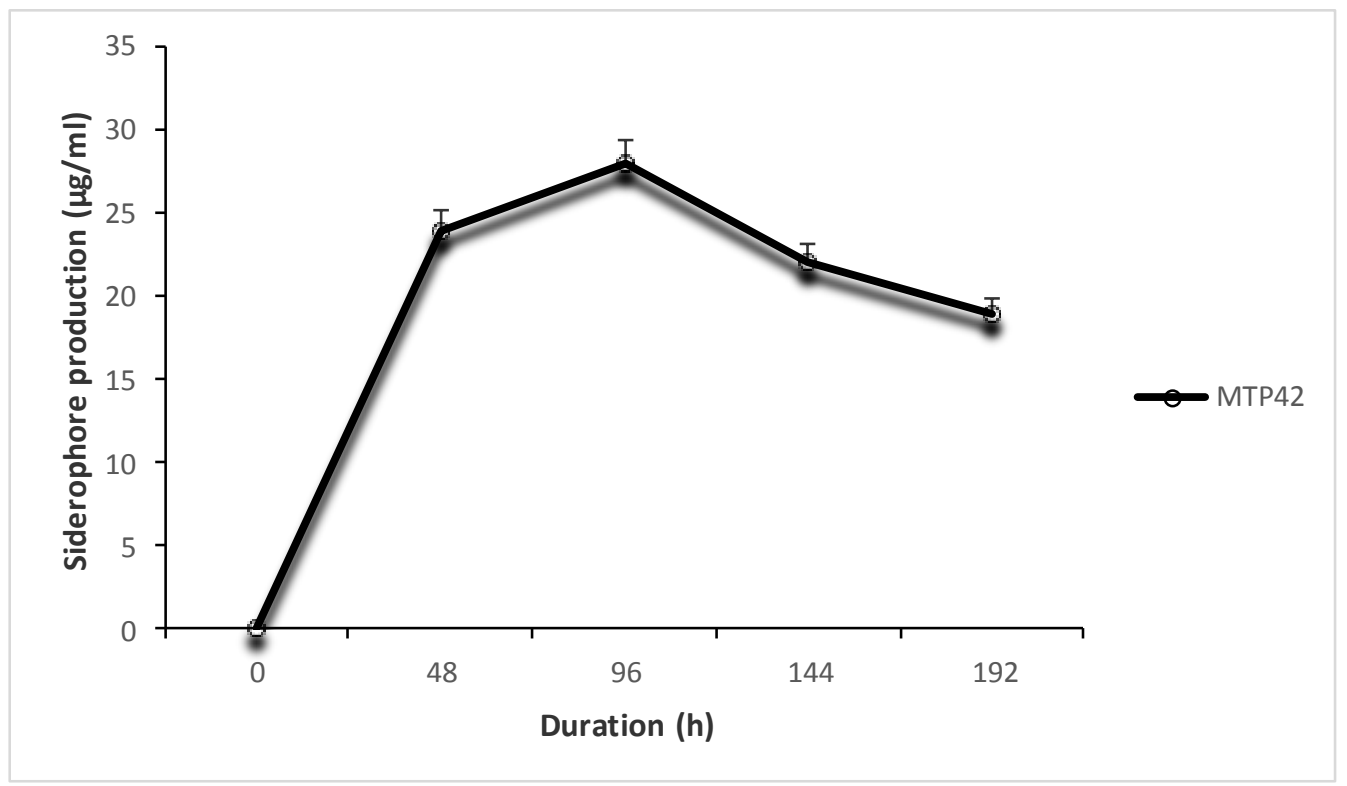

Table.1 Morphological, physiological and biochemical characterization of MTP42

\begin{tabular}{|l|l|l|l|l|l|l|l|l|l|}
\hline \multicolumn{2}{|c|}{ Morphological and physiological characteristics } \\
\hline Test & $\begin{array}{l}\text { Morphology } \\
\text { arrangement }\end{array}$ & $\begin{array}{l}\text { Gram } \\
\text { staining/Pigmentation }\end{array}$ & Motile & urease & starch & Glucose & lactose & sucrose \\
\hline $\begin{array}{l}\text { MTP } \\
\text { 42 }\end{array}$ & $\begin{array}{l}\text { Rod and } \\
\text { single }\end{array}$ & $\begin{array}{l}\text { Pink and no } \\
\text { pigmentation }\end{array}$ & -ve & -ve & -ve & +ve & +ve & +ve \\
\hline Biochemical characteristics & catalase & $\mathrm{H}_{2} \mathrm{~S}$ & $\begin{array}{l}\text { Nitrate } \\
\text { reduction }\end{array}$ & Indole & $\begin{array}{l}\text { Methyl } \\
\text { red }\end{array}$ & $\begin{array}{l}\text { Voges } \\
\text { proskuaer }\end{array}$ & $\begin{array}{l}\text { Citrate } \\
\text { utilization }\end{array}$ \\
\hline $\begin{array}{l}\text { Test } \\
\text { oxidase }\end{array}$ & -ve & -ve & +ve & -ve & -ve & -ve & +ve \\
\hline $\begin{array}{l}\text { MTP } \\
\text { 42 }\end{array}$ & -ve & & & & & \\
\hline
\end{tabular}

Table.2 Change in $\mathrm{pH}$ during $\mathrm{P}$ solubilisation upto 21 st day after incubation

\begin{tabular}{lllll}
\hline Isolate & $\mathbf{0}$ day & $\mathbf{7}^{\text {th }}$ day & $\mathbf{1 4}^{\text {th }}$ day & $\mathbf{2 1}^{\text {st }}$ day \\
\hline MTP42 & 7.1 & 4.54 & 4.24 & 3.4 \\
\hline
\end{tabular}

HCN production was checked in all isolates which showed significant results in phosphate solubilisation and IAA production potential.

It showed $\mathrm{HCN}$ production after 42 and $72 \mathrm{~h}$ of incubation. It shows a significant potential against phytopathogens. Cattelan et al., (2007) reported that production of cyanide was an important trait in controlling fungal diseases in wheat seedlings under in-vitro conditions. Chandra et al., (2007) reported production of $\mathrm{HCN}$ by the PGPR which was inhibitory to the growth of $S$. sclerotium. Kumar et al., (2008) also reported in vitro antagonism by HCN producing PGPR against sclerotia germination of $M$. phaseolina. 


\section{Exopolysaccharide (EPS) production}

The EPS produced by the isolate MTP 42 was observed to be $(31 \mathrm{mg} / \mathrm{ml})$ after five days of incubation. Sucrose was found to give better production of EPS as compared to other carbon sources. EPS production was higher during the early stationary phase compared to the late stationary of the isolate (Modi et al.,). Borgio et al., (2009) reported three bacterial strains, bacillus subtilis NCIM 2063

After seven days of incubation the isolate MTP 42 showed high phosphate solubilization. $37^{\circ} \mathrm{C}$ temperature, $0.7 \%, \mathrm{NaCl}$ (salinity), $\mathrm{pH} 7$ and Glucose were identified as influencing factors for optimization of growth and maximum phosphate solubilization. In the present study MTP 42 showed significant production of ammonia and strong phosphate solubilization. This infers that MTP 42 isolate in the rhizosphere makes ammonia and phosphorus available to the plant by which nutritional needs of the plant can be fulfilled.

The morphological and biochemical analysis indicated highest (98\%) similarity of the isolate with the genus Stenotrophomonas when compared with Bergey's Manual of Determinative Bacteriology (Holt et al., 1994). In addition the phenotypic characteristic of this species correlate well with the molecular analyses based on $16 \mathrm{~s}$ rRNA partial sequence analyses. Naz et al., (2010) identified phosphate solubilizing bacteria belonging to genera Stenotrophomonas maltophilia by 16s rRNA.

Microbial PGPR has been implicated in the stimulation of growth or pathogenesis of plants. A diverse group of microbes, including soil, epiphytic and tissue colonizing bacteria have been found to synthesize IAA (Patten, 1996). In this study bacterial strains produced considerable amount of phosphate, ammonia and $\mathrm{HCN}$, which is comparable with earlier studies on various bacteria including Pseudomonas and Stenotrophomonas (Malik et al., 1997). This study reports the isolation and characterization of the strain $S$. Maltophilia MTP 42 from the rich rhizosphere soils of Coleus plant confirming their plant growth potential. Bacteria from this genus was generally regarded as good phosphate solubilizers and as biofertilizers (deFreitas et al., 1997). So it clearly reveals that apart from the normally encountered rhizosphere microflora: Azospirillum, Azotobacter, Herbaspirillum, Klebsiella, etc., other species may also possess diazotrophy. $S$. Maltophila has an ambivalent character, first as a biocontrol and bioremediation agent and second as a multiresistant pathogen in nosocomial infections. There are numerous reports on the isolations from diverse rhizospheres. The clinical isolates are separated from the rhizosphere isolates by $16 \mathrm{~s}$ rdna analysis (Minkwitz, 2001). However it requires further studies on the virulence of the rhizosphere isolates before recommending it as a bioinoculant.

Conventionally, insoluble phosphates are chemically processed by reacting with sulphuric acid or phosphoric acid into soluble $\mathrm{P}$. However, this process increases $\mathrm{P}$ fertilizer cost, and has environmental implications. In view of environmental concerns and current developments in sustainability, research efforts are concentrated on the development of a technique that uses phosphate solubilizing microorganisms to solubilize insoluble phosphates (Biswas, 2006). However, the mechanism of phosphate solubilization by microorganisms is also a subject of controversy today. Therefore, it needs further studies to understand the characteristics and mechanisms of phosphate solubilization by phosphate solubilizing microorganisms. Moreover, the role of phosphate solubilizing microorganisms on 
plant growth under field conditions is also important and necessary to be studied.

It is expected that this report will prompt further screenings of phosphate solubilizing microorganisms so as to enhance agronomic value of soils and benefit crop growth. Evaluation of this isolate under the field condition and thorough investigation of Stenotrophomonas maltophilia MTP 42 use as a plant growth promoting rhizobacterial agent constitute future research. This shows that multiple potential of MTP 42 can help in plant protection and enhance plant growth.

\section{References}

Adesemoye, A. O., and Egamberdieva, D. (2013). Beneficial effects of plant growth-promoting rhizobacteria on improved crop production: prospects for developing economies. In Bacteria in agrobiology: Crop productivity (pp. 4563). Springer Berlin Heidelberg.

Ali, B., Sabri, A. N., Ljung, K., and Hasnain, S. (2009). Auxin production by plant associated bacteria: impact on endogenous IAA content and growth of Triticum aestivum L. Letters in applied microbiology, 48(5), 542-547.

Arnow, L. E. (1937). Colorimetric determination of the components of 3 , 4-dihydroxy phenylalanine-tyrosine mixtures. J. biol. Chem, 118(2), 531537.

Bazzicalupo, M., Fani, R., Humana Press., Inc., Totowa, NJ.,112-124, 1995.

Berg, G., Roskot, N., and Smalla, K. (1999). Genotypic and phenotypic relationships between clinical and environmental isolates of Stenotrophomonas maltophilia. Journal of clinical microbiology, 37(11), 3594-3600.

Biswas D R, Narayanasamy G. "Rock phosphate enriched compost: An approach to improve low-grade Indian rock phosphate[J]", Bioresour Technol, 97: 2243-2251, 2006.

Davey, M. E., and O'toole, G. A. (2000). Microbial biofilms: from ecology to molecular genetics. Microbiology and molecular biology reviews, 64(4), 847867.

deFreitas, J.R., Banerjee, M.R., Germida, J.J., "Phosphate solubilizing rhizobacteria enhance the growth and yield but not phosphorus uptake of Canola (iL.)", Biol. Fert. Soils 24, 358-364, 1997.

Gaur, A.C., 1990. In: Phosphate Solubilizing Microorganisms as Biofertilizer. Oxford Publishing, New Delhi, pp. 26-29

Glick, B. R. (2012). Plant growth-promoting bacteria: mechanisms and applications. Scientifica, 2012.

Gopalakrishnan S, Humayun P, Srinivas Vadlamudi S, Vijayabharathi R, Bhimineni RK, Rupela O (2012) Plant growth-promoting traits of Streptomyces with biocontrol potential isolated from herbal vermicompost. Biocontrol Sci Technol 22:1199-1210

Haldar, S., and Sengupta, S. (2015). Plantmicrobe cross-talk in the rhizosphere: insight and biotechnological potential. The open microbiology journal, 9, 1.

Holt, J.G., N.R. Kreig, P.H.A Sneath, J.T. Staley and S.T. Williams, "Bergey's Manual of Determinative Bacteriology", Williams and Wilkins, Baltimore, USA, pp. 40-169, 1994.

Krogan, N. J., Cagney, G., Yu, H., Zhong, G., Guo, X., Ignatchenko, A., and Punna, T. (2006). Global landscape of protein complexes in the yeast Saccharomyces cerevisiae. Nature, 440(7084), 637-643.

Kuang-Ren, C., Turksen, S., Umran, E., Timmer, L. W., Peter, P.U,. 2003. "Indole derivatives produced by the fungus Colletotrichum acutatum causing lime anthracnose and 
postbloom fruit drop of citrus," FEMS Microbiology Letters, 226:23-30.

Kumar, A., Kumar, V., and Kharwar, R. N. (2007). Induced Resistance: A Bio technological Approach for Induction of Defense-related Molecules in Plant Disease Management. Microbial Diversity: Modern Trends, 128.

Kumar, N. P., and Audipudi, V. (2015). Exploration of a novel plant growth promoting bacteria Stenotrophomonas maltophilia AVP27 isolated from the chilli rhizosphere soil. Int. J. Eng. Res. Gen. Sci, 3, 265-276.

Li, K., Pidatala, V. R., Shaik, R., Datta, R., and Ramakrishna, W. (2014). Integrated metabolomic and proteomic approaches dissect the effect of metalresistant bacteria on maize biomass and copper uptake. Environmental science and technology, 48(2), 1184-1193.

Malik, K.A., Bilal, R., Mehnaz, S., Rasul, G., Mirza, M.S., Ali, S., "Association of nitrogen fixing and plant growth promoting

Malik, K.A., Bilal, R., Mehnaz, S., Rasul, G., Mirza, M.S., Ali, S., "Association of nitrogen fixing and plant growth promoting rhizobacteria (PGPR) with kallar grass and rice”, Plant Soil 194, 37-44, 1997.

Minkwitz, A., Berg, G., "Comparison of antifungal activities and $16 \mathrm{~S}$ ribosomal DNA sequences of clinical and environmental isolates of Stenotrophomonas maltophilia, J. Clin. Microbiol. 39, 139-145, 2001.

Mody, B., Bindra, M., and Modi, V. (1989). Extracellular polysaccharides of cowpea rhizobia: compositional and functional studies. Archives of microbiology, 153(1), 38-42.

Mohite, B. (2013). Isolation and characterization of indole acetic acid (IAA) producing bacteria from rhizospheric soil and its effect on plant growth. Journal of soil science and plant nutrition, 13(3), 638-649.

Narayanasamy, P. (2013). Biological management of diseases of crops. Springer.

Naz I., A. Bano and Tamoor-ul-Hassan, "Morphological, biochemical and molecular characterization of rhizobia from halophytes of Khewra salt range and Attock", Pak. J. Bot., 41(6): 31593168, 2009.

Pandey, P., and Maheshwari, D. K. (2007). Two-species microbial consortium for growth promotion of Cajanus cajan. Current Science (00113891), 92(8).

Pandey, P., Kang, SC., Maheswari, DK., Isolation of endophytic plant growthpromoting Burkholderia spp. MSSP from root nodules of Mimosa pudica. Curr Sci, 89(1): 177-180, 2005.

Patten, C.L., Glick, B.R., "Bacterial biosynthesis of indole-3-acetic acid", Can. J. Microbiol. 42, 207-220, 1996.

Pielach, C. A., Roberts, D. P., and Kobayashi, D. Y. (2008). Metabolic behavior of bacterial biological control agents in soil and plant rhizospheres. Adv ApplMicrobiol, 65, 199-215.

Ptak, A., Moranska, E., Simlat, M., Skrzypek, E., Warchol, M., and Nowak, M. (2015). The effect of sugars on in vitro growth of Leucojum aestivum L. plants. BioTechnologia. Journal of Biotechnology Computational Biology and Bionanotechnology, 96(1).

Ramadan, E. M., AbdelHafez, A. A., Hassan, E. A., and Saber, F. M. (2016). Plant growth promoting rhizobacteria and their potential for biocontrol of phytopathogens. African Journal of Microbiology Research, 10(15), 486504.

Rania, A. B. A., Jabnoun-Khiareddine, H., Nefzi, A., Mokni-Tlili, S., and DaamiRemadi, M. (2016). Endophytic bacteria 
from Datura metel for plant growth promotion and bioprotection against Fusarium wilt in tomato. Biocontrol Science and Technology, 26(8), 11391165.

Saharan, B. S., and Nehra, V. (2011). Plant growth promoting rhizobacteria: a critical review. Life Sci Med Res, 21(1), 30.

Sarwar, M., Arshad, M., Martens, D. A., and Frankenberger, W. T. (1992). Tryptophan-dependent biosynthesis of auxins in soil. Plant and Soil, 147(2), 207-215.
Tabatabai, M. A., and Bremner, J. M. (1969). Use of p-nitrophenyl phosphate for assay of soil phosphatase activity. Soil biology and biochemistry, 1(4), 301307.

Tamura, K., Dudley, J., Nei,M., Kumar, Sm., MolBiolEvol, 24, 159601599, 2007

Tilak, K. V. B. R.,Ranganayaki, N., Pal, K. K., De, R., Saxena, A. K., Nautiyal, C. S., and Johri, B. N. (2005). Diversity of plant growth and soil health supporting bacteria. Current science, 89(1), 136150.

\section{How to cite this article:}

Tisha Patel and Meenu Saraf. 2017. Exploration of Novel Plant Growth Promoting Bacteria Stenotrophomonas maltophilia MTP42 Isolated from the Rhizospheric Soil of Coleus forskohlii. Int.J.Curr.Microbiol.App.Sci. 6(11): 944-955. doi: https://doi.org/10.20546/ijcmas.2017.611.111 